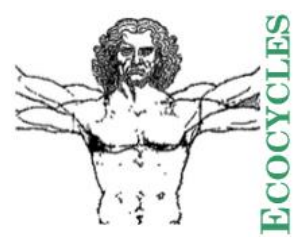

Ecocycles, Vol. 7, No. 1, pp. 47-51 (2021)

DOI: $10.19040 /$ ecocycles.v7i1.190

\title{
OBITUARY
}

\section{This is my life}

\section{In Memory of Professor Zoltan Kiraly (1925-2021)}

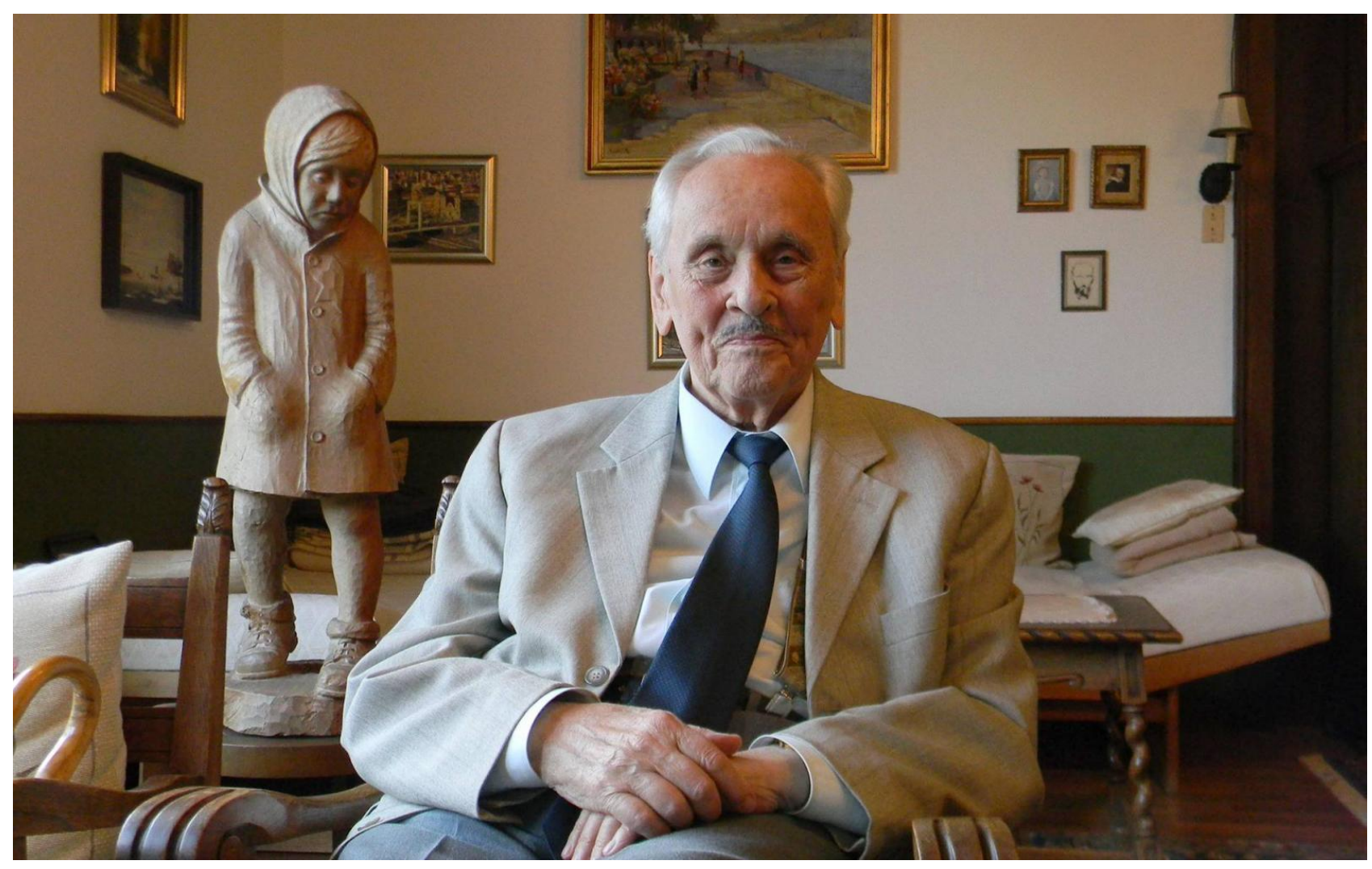

Zoltan Kiraly at his home in Budapest in 2013 (photo from Magyar Szo [accessed 06.10.2021], reproduced with permission)

\section{Tamas Komives ${ }^{1,2}$}

\footnotetext{
${ }^{1}$ Plant Protection Institute, Centre for Agricultural Research, Eotvos Lorand Research Network, Herman Otto 15, 1022 Budapest, Hungary; ${ }^{2}$ Institute of Agricultural Sciences and Environmental Management, Hungarian University of Agriculture and Life Sciences, Matrai ut 36, 3200 Gyongyos, Hungary

\section{E-mail address: komives.tamas@atk.hu}

\begin{abstract}
This is the obituary of Professor Zoltan Kiraly (1925-2021), plant scientist, co-creator of the scientific discipline of plant pathophysiology.
\end{abstract}

Keywords - Professor Zoltan Kiraly, plant pathology and pathophysiology, obituary.

It was with great sadness that we learned of the death of Professor Dr. Zoltan Kiraly, plant pathologist, one of the founders of the scientific field of plant pathophysiology, a talented and internationally recognized scientist and educator admired by many, a distinguished professor of several universities, member of the Hungarian Academy of Sciences (HAS), and director of the Plant Protection Institute of HAS, who lived for ninety-six years. He had a great impact on the 
international advancement of plant pathophysiology, on Hungarian scientific life, on the spirit of his Institute, and on his contemporaries and university students both within and outside the country.

He has received numerous awards for his scientific performance, including the Academic Prize of HAS (1972), Honorary Professor (1972, Pannon Agricultural University, Keszthely), State Prize of the Presidential Council of Hungary (1983), Honorary Professor (1996, University of Horticulture, Budapest), Honorary Professor (1998, University of Agricultural Science, Godollo), Honorary Professor (1998, University of Agricultural Science, Debrecen), Honorary Professor (2003, University of West-Hungary, Mosonmagyarovar), Exceptional Quality Award (2004, Akademiai Kiado, Budapest), and Golden Medal of the HAS (2013, Budapest).

Zoltan Kiraly was one of the most prominent natural scientists of Hungary: a giant in plant science and recognized as such across a broad range of fields and professions. On his shoulders, dozens of researchers (students and fellow scientists) stood over the course of the years. Although beyond a particular level of scientific accomplishments, numbers are meaningless, still, it is worth mentioning that Zoltan Kiraly's Google Scholar profile lists more than seven thousand citations for his ca. 350 publications.

Zoltan Kiraly was born in Obecse in 1925 (at that time Yugoslavia, before World War I the Kingdom of Hungary, today Serbia), in the midst of turbulent historical events. During his early childhood, his family left their hometown and, seeking a better life, moved to Szeged, Hungary, and later to Budapest.

Already at a young age, Zoltan Kiraly was blessed with outstanding memory and knowledge recall. He showed astounding excellence and a deep affinity to science during his elementary and high school studies. At the age of fifteen, he was a great respecter of Professor Albert Szent-Gyorgyi (a Nobel-prize winner in Physiology and Medicine in 1937) and even 80 years later he vividly remembered the interview the professor gave to the Hungarian Radio in 1941. The interview began with the sentence "Here we are sitting in the kitchen of the Nobel-prize winning scientist who is busy peeling a basketful of potatoes". The explanation for the amusing situation was that the potatoes were prepared for the laboratory experiments the next day. In the 2010s, when the archives of the Hungarian Radio were digitalized and became accessible online, Zoltan Kiraly was very excited that he could listen to the interview again.

Zoltan Kiraly entered the Hungarian Royal Jozsef Nador University of Technology and Economics in 1944 where he studied agronomy and obtained his degree in 1948. He was most interested in research, and early in his career, he worked at different institutions. His first internship started at the Plant Protection Institute of the Ministry of Agriculture in Budapest. Then, he worked at the Hungarian Royal Experiment Station for Animal Physiology and Feeding (Budapest) for one year. Between 1951 and 1955 he was a coworker at the Research Institute for Agriculture of the HAS in Martonvasar. It was in this Institute where he met an exceptionally talented and committed young colleague, Gabor Farkas. The two were almost mirror images of each other: beautiful minds, born in the same year, equally ambitious, hardworking, open-minded, having identical world views. Soon they started to work together and became inseparable, lifelong friends and collaborators, strongly challenging, influencing, and encouraging each other until the untimely death of Gabor Farkas at the age of 61.

Their initial research cooperation focused on the physiology of diseased plants. At that time, this field was a barely elaborated frontier of plant physiology and plant pathology, although pioneering (and later forgotten) studies of the Hungarian scientist Geza Doby need to be mentioned here (Doby, 1911). In 1956 Zoltan Kiraly moved back to the Plant Protection Institute and Gabor Farkas followed him in 1957 so that they could continue their cooperation. As a result of their joint efforts, the "Hungarian School of Plant Pathophysiology" was established, members of which soon gained nationwide and later international reputation. Zoltan Kiraly continued to work for this Institute for 56 years (first as a senior researcher, later as a department head, and between 1980 and 1993 as the Institute's director) until his retirement in 2012 .

Together with Gabor Farkas and other members of their School, Zoltan Kiraly discovered substantial changes in enzyme activities in diseased plant tissues and demonstrated their importance in pathological interactions, symptomatology, processes, and disease resistance. His team worked enthusiastically and ambitiously to become experts and leaders in this new scientific field and strongly motivated each other to secure an international reputation. In order to achieve their goals they aimed to publish their most important findings in internationally recognized (i.e., Western) scientific journals - although this research attitude was not without risks in communist Hungary. Later on, Gabor Farkas formed a research group of the HAS at the Eotvos Lorand University in Budapest, but he remained in close contact with Zoltan Kiraly.

Another excellent scientist and colleague of Zoltan Kiraly was Zoltan Klement, who became well known and respected in the scientific world due to his pioneering work on the hypersensitive reaction of plants to phytopathogenic bacteria. They worked in neighboring laboratories and were very good friends not only in the institute but in private life as well.

In recognition of his scientific accomplishments, Zoltan Kiraly was promoted to Head of the Plant Pathology Department of the Institute in 1963 and he methodically started to expand his School by attracting young researchers to his department. As a department head and later as a director he often emphasized the importance of certain personal traits and competencies that he thought were necessary to accomplish scientific discoveries, such as 1) tidiness (in the laboratory, notes, presentations, appearance, speech, etc.), 2) 
hard work, 3) proficiency in languages (most importantly in English), 4) international scientific connections and cooperation, 5) working abroad in prestigious laboratories, 6) publishing in esteemed journals and giving presentations at international conferences, 7) being knowledgeable in fields related to plant protection (agriculture, biology, breeding, chemistry, biochemistry, microbiology, etc.), 8) reading international journals to stay up-to-date on new discoveries, research trends, grants, and awards.

As a director, he played an instrumental role in defining and maintaining the Institute's modern work profile, with a focus on the widespread introduction of the latest scientific approaches and techniques, including molecular biology.

He was a dedicated scientist with a very broad spectrum of interests. In addition to phytopathology, he was deeply involved in many aspects of life sciences from microbiology to botany, evolution, genetics, and many more. During his teaching and research career, he oversaw the experiments of dozens of teammates in his laboratory: students (graduate and $\mathrm{PhD}$ ), postdoctoral scientists, and guest researchers from all locations around the world investigating a broad spectrum of subjects. He was a fantastic lecturer and teacher who was well-liked and respected. Furthermore, he was an excellent mentor who closely supervised the work of every coworker of his research team, focusing his attention on the success of his students, many of whom later became internationally renowned experts in plant science. He emphasized the importance of scientific curiosity and critical thinking. A significant part of his legacy is his participation in creating plant science talent among dozens of researchers and students.

His scholarly papers have been published in the most important journals of natural sciences. According to his Google Scholar profile, his most cited publication $(>580$, [Goodman et al., 1986]) is a textbook he co-authored with his friend Professor Robert Goodman (University of Missouri, Columbia). His other high-impact papers (cited more than 200 times) involve research on the role of the superoxide anion in the bacterially induced hypersensitive reaction (HR) in tobacco (Adam et al., 1989) and on the effect of ferritin on oxidative damage and pathogens (Deak et al., 1999), a textbook on breeding for disease resistance (Kiraly et al., 1970), and a comparative study on the effects of tobacco mosaic virus infection and salicylic acid on systemic acquired disease resistance of plants (Fodor et al., 1997).

He considered that observations related to the roles of HR and reactive oxygen species (ROS) in plant disease resistance were his most important scientific findings. In the 60s and $70 \mathrm{~s}$, there was a widespread misconception that resistance is caused by HR. Zoltan Kiraly and his colleagues showed that $\mathrm{HR}$ is a consequence and not the cause of plant disease resis-

\footnotetext{
${ }^{1}$ To acknowledge, commemorate, and celebrate the contributions of Hungarian scientists of the "golden era" to modern mathematics and
}

tance. This skeptical experimental result was published in the journal Nature (Kiraly et al., 1972). Later, they demonstrated that the essence of plant immunity lies, at least in part, in the controlled synthesis and detoxification of ROS (Barna et al., 2012).

\section{A NURTURING ENVIRONMENT}

One can only speculate what made Zoltan Kiraly (and many Hungarian scientists of his generation) so successful internationally - against all odds. After all, World War II just ended when they started their career: the country was devastated, all cities and factories were demolished, and the economy was in ruins. A possible explanation is related to events that took place about five-six decades earlier, at the turn from the nineteenth to the twentieth century when Hungary underwent rapid industrial development and immense financial prosperity. This allowed the country to establish a world-class education system that produced a wave of Nobelprize-winning scientists. ${ }^{1}$ Zoltan Kiraly often talked about his superb teachers and professors (all of whom obtained their education in this "golden era" of Hungarian science). An additional genius loci that positively influenced professional advancement was his workplace, the Plant Protection Institute: the milieu he enjoyed as a young scientist (and later shaped as its director). Although the Institute's building was ruined and burned during World War II (Komives and Kiraly, 2019), its eminent research staff was intact and already incorporated about half a dozen young, highly-skilled, mission-driven scientists, thereby creating a nurturing, cooperating, and stimulating environment for Zoltan Kiraly.

\section{ON A PERSONAL NOTE}

Zoltan Kiraly greatly appreciated the company of friends, the heart-to-heart atmosphere. In addition to his continuous, unrelenting dedication to and focus on science, Zoltan Kiraly adored conversing about an astonishingly wide array of seemingly unrelated subjects: spiritual matters, classical arts, and literature (he was a devoted admirer and expert of Fyodor Dostoyevsky's works), religion, philosophy, history, architecture, customs and traditions, travel, the diversity of cultures, politics, science policy, and sports events (football before anything else, and strangely enough, boxing). Being able to be touched by virtue, grace, and decency, he took genuine pleasure in friendship: he longed and enjoyed being loved.

I believe that two of Zoltan Kiraly's most outstanding personal features were his extraordinary diligence and his clearmindedness. When evaluating complex scientific or managerial tasks, he could quickly distinguish the essential from the less important: this ability gave him a huge advantage in every walks of life.

physics, Smil published a paper in Nature with the title "Genius loci. The twentieth century was made in Budapest" (Smil, 2001). 
Zoltan Kiraly respected great scientists above all. He looked forward to the yearly announcements for the Nobel prizes, and read the justifications carefully, with great excitement. He did this with a keen critical eye: did the winners become world-famous based on real achievements? This nonbiased, balanced frame of mind helped him to judge and live with his own aging and prolonged suffering for being bed-ridden for the last three years of his life.

His exceptional social, linguistic, and negotiating abilities made him perfectly suited to entertain smaller or larger audiences with jokes, stories, and literary quotes. As regards quotes, when wines were served at the table (on any occasion, e.g., at a conference dinner) Zoltan Kiraly often recited the first paragraph of Goethe's poem "Trunken müssen wir alle sein!" (Goethe, 1819), and a longer paragraph of Sandor Marai's short essay on Hungarian wines "...there is no better place to die than under a walnut tree before a wine cellar in autumn time, right after harvest, when the young wine is dozing and being fermented in the wine casks, the walnuts have been beaten from the tree and the sun still has its faint strength the same way as old men's love does..." (Marai, 1941). [A complete translation of the essay is readable in the Supplement to this paper: it has been reproduced with $\mathrm{Mr}$. Gabor Gyukics's (the translator) permission].

\section{THIS IS MY LIFE}

On a hot summer day in 1993, Zoltan Kiraly was driven to the Budapest Airport to receive a foreign visitor to his laboratory. While still in the city, he suffered a major heart attack. Luckily, the driver managed to stop at a pharmacy, from where an ambulance was quickly called. Zoltan Kiraly was taken to a hospital, and his life was saved. The doctors told him to stay home and rest for at least one month. However, after two weeks he was back in the Institute, reading and writing letters and correcting manuscripts at his desk. When colleagues politely told him that he is risking his life by disobeying the doctors, he, with an apologetic look on his face, replied: "But this is my life..." - and quietly continued his work.

In his office, in the laboratory, or on the professor's pulpit, Zoltan Kiraly was known to work with great vigor, commitment, passion, and excitement. Still, he lived his life to the fullest, as a passionate singer and guitar player, an expert on fine arts, wine and cuisine, and a collector of antique books, paintings, and sculptures. The home of the Kiralys in the Buda hills of the capital has served as a gathering place for scientists, scholars, educators, artists, and journalists from throughout the world.

Zoltan Kiraly will be sorely missed by his friends, former colleagues, and graduate and postgraduate students all around the world, all of whom wish to express their condolences to his wife. Zsuzsa and children Nora, Lorant, and Viktor.

Through his books and papers, colleagues, coworkers, and friends Zoltan Kiraly's exceptional personal qualities and scientific achievements will serve as a challenge and a source of encouragement and inspiration for many aspiring researchers.

\section{OPEN ACCESS STATEMENT}

This article has been published under a Creative Commons Attribution 4.0 international license that provides immediate open access to its content on the principle that making research freely available to the public supports a greater global exchange of knowledge.

\section{ACKNOWLEDGMENTS}

I acknowledge with thanks Drs. Balazs Barna and Lorant Kiraly (Plant Protection Institute, ARC, ELRN, Budapest, Hungary) and Professor Laszlo Hornok (Agricultural University of Hungary, Godollo) for their suggestions and constructive criticism, and Mr. Gabor Gyukics for his permission to republish his translation as an attachment to this paper.

\section{REFERENCES}

Adam, A., Farkas, T., Somlyai, G., Hevesi, M., Kiraly, Z., 1989. Consequence of O2-- generation during a bacterially induced hypersensitive reaction in tobacco: deterioration of membrane lipids. Physiol. Mol. Plant Pathol. 34, 13-26. DOI: $10.1016 / 0885-5765(89) 90013-1$

Barna, B., Fodor, J., Harrach, B.D., Pogany, M., Kiraly, Z., 2012. The Janus face of reactive oxygen species in resistance and susceptibility of plants to necrotrophic and biotrophic pathogens. Plant Physiol. Biochem., Reactive Oxygen, Nitrogen, Carbonyl and Sulfur Species in Plants 59, 37-43. DOI: 10.1016/j.plaphy.2012.01.014

Deak, M., Horvath, G.V., Davletova, S., Török, K., Sass, L., Vass, I., Barna, B., Kiraly, Z., Dudits, D., 1999. Plants ectopically expressing the iron-binding protein, ferritin, are tolerant to oxidative damage and pathogens. Nat. Biotechnol. 17, 192-196.

DOI: $\underline{10.1038 / 6198}$

Doby, G., 1911. A biochemical study of the leaf-roll disease of the potato. I. The oxidases of the tubers (in German). Z. fur Pflanzenkrankh. 21, 10-17.

Fodor, J., Gullner, G., Adam, A.L., Barna, B., Komives, T., Kiraly, Z., 1997. Local and systemic responses of antioxidants to tobacco mosaic virus infection and to salicylic acid in tobacco (role in systemic acquired resistance). Plant Physiol. 114, 1443-1451.

DOI: $10.1104 / p p .114 .4 .1443$

Goethe, J.W., 1819. Gedichte. West-östlicher Divan. Cotta, Stuttgart u. Tübingen.

Kiraly, Z., Barna, B., Ersek, T., 1972. Hypersensitivity as a consequence, not the cause, of plant resistance to infection. Nature 239, 456-458.

DOI: $\underline{10.1038 / 239456 \mathrm{a} 0}$ 
Kiraly, Z., Klement, Z., Solymosy, F., Voros, J., 1970. Methods in plant pathology with special reference to breeding for disease resistance. Elsevier Scientific Pub. Co.

Komives, T., Kiraly, Z., 2019. Cultural heritage - the first research campus in Hungary. Ecocycles 5, 6-11.

DOI: $10.19040 /$ ecocycles.v5i2.145
Marai, S., 1941. Hungarian wines (in Hungarian). Budapest.

Smil, V., 2001. Genius loci: The twentieth century was made in Budapest. Nature 409, 21-21.

DOI: $10.1038 / 35051162$

(C) 2021 by the author(s). This article is an open-access article distributed under the terms and conditions of the Creative Commons Attribution (CC BY) license (http://creativecommons.org/licenses/by/4.0/). 